\title{
'We Serve the People of Europe': Reimagining the ECB's Political Master in the Wake of Its Emergency Politics
}

\author{
Hjalte Lokdam, LSE
}

\begin{abstract}
In the wake of the Euro crisis, the mission statement on the European Central Bank's (ECB) website was changed from 'Our mission is to serve Europe's citizens' to 'Our mission is to serve the people of Europe'. This article situates this discursive shift within a broader change of the ECB's self-presentation in public discourses and explores its meaning in terms of political theory and public law. The article argues that the shift represents a response to the perceived necessity of reimagining the ECB's foundation of legitimate governmental authority following its exercise of emergency powers during the Euro crisis. The discourse emphasizes an organic link between the ECB and 'the people of Europe' as a political subject able to authorize previously unauthorized governmental practices such as the outright monetary transactions programme. It reflects, furthermore, a new governing philosophy that stresses flexibility and discretion rather than strict adherence to rules in the ECB's exercise of power.
\end{abstract}

\section{Acknowledgments}

This article develops an argument first outlined in my blog post 'Is the European Central Bank Becoming a Central Bank for the People of Europe?' (Verfassungsblog, 24 April 2016). Jonathan White and Michael Wilkinson encouraged me to develop it further and for that I am grateful. Early versions were presented in 2017 at the "European Central Banking Workshop" at the Institute for European Studies, University of British Columbia and at the EUSA Conference in Miami. I would like to thank the participants in these events for valuable input, especially Michele Chang, Sebastian Diessner, Sebastian Heidebrecht, Sven Hilgers, Signe Larsen and Daniel Schulz. I would also like to thank the three anonymous reviewers whose comments, critiques and suggestions helped improve the quality of the manuscript tremendously. Finally, I would like to thank a number of current and former employees of the ECB for productive discussions about some of the issues raised in this article. 
We serve the people of Europe by protecting the value of the euro and keeping prices stable.

From the ECB's website ${ }^{1}$

\section{INTRODUCTION}

The European Central Bank (ECB) was central to the emergency politics of the Eurocrisis. As a result of the Crisis, the ECB's role in Eurozone governance has both widened and deepened. Through its 'unconventional monetary policies' and involvement in the Troika, the ECB pushed its legal mandate to the limit, if not beyond (Beukers, 2013; Braun, 2017). With the creation of the Banking Union its formal responsibilities were expanded considerably beyond a narrow focus on price stability (Howarth and Quaglia, 2013; Papasavvas, 2015; De Rynck, 2016; Lamandini et al., 2016). In facilitating such changes the ECB, and its President Mario Draghi in particular, exercised 'charismatic' leadership and filled a political vacuum at the heart of the Eurozone (Tortola and Pansardi, 2019; Torres, 2013; Habermas 2015; Verdun 2017). In so doing, the ECB acted not merely on the basis of its price stability mandate, but as if its mandate were to secure the political stability and security of the Eurozone. The ECB, in other words, became a political actor in a manner that far exceeded the traditional understanding of its monetary policy mandate.

The ECB's acts have raised concerns about the legal status of the ECB's powers as well as the democratic legitimacy of their expanded reach (see, e.g., Braun, 2017;

\footnotetext{
${ }^{1}$ From the web page 'Who we are,' available at: https://www.ecb.europa.eu/careers/working-atthe-ecb/html/index.en.html [accessed 22 May 2019].
} 
Curtin, 2017; Goldoni, 2017). This concern is explicitly recognised by the ECB. As Draghi (2013) put it, '[g]reater authority at the European level must be matched by greater democratic legitimacy' (see also, e.g., Draghi, 2012, Mersch, 2017; Fraccaroli et al, 2018). Benoît Cœuré (2013), member of the ECB's Executive Board, has similarly suggested that democratic processes at the European level must be strengthened in order to secure 'an anchor for' effective crisis measures now and in the future. In the wake of the Crisis, he suggested, 'a redefinition of the social contract in Europe is essential.'

This article examines the ECB's attempts to grapple with the disjuncture between the formal legal authorisation of the ECB's powers and the expanded range of those powers in the wake of the Eurocrisis. In doing so, it examines the political theory undergirding the discourse employed by the ECB in order to make sense of and justify its emergence as a powerful political actor on the European stage. In defending its acts as more than unfounded transgressions of the European social contract, this article shows that the ECB invokes and appeals to the political will of the people of Europe. The ECB thereby reimagines its foundation of authority as being based not so much on the law of the Treaties as on an organic political relationship with the people of Europe as a subject of legitimation.

The significance of the shift from a legal to a political foundation of authority is potentially expansive. In line with the general paradigm of liberal constitutionalism, the 'legal' foundation of authority is based on an explicit and positive expression of political will in the past. It entails significant constraints on the ECB because it relies on a formal enumeration and limitation of powers. A 'political' foundation of authority, on the other hand, is based on an organic relationship between rulers and ruled. It offers a considerably wider degree of flexibility and open-endedness in the exercise of governmental powers because these powers are (informally) authorised in the present. In the case of the ECB, 
it allows for a more discretionary governing philosophy and for the notion that acts of the ECB are implicitly authorised, and thereby legitimate, unless political will is explicitly and effectively expressed against them. An organic link between the ECB and the people of Europe thus provides a justification for the ECB's expanded mandate and role in Eurozone governance in and following the Eurocrisis.

The article proceeds in two main sections. The first section analyses the tensions between the ECB's legal mandate and its Outright Monetary Transactions (OMT) programme. Prefigured in Draghi's (2012) famous 'whatever it takes'-speech, the OMT programme was paradigmatic because it raised questions about the meaning and limits of the ECB's core monetary policy mandate. Although never actually triggered, the programme involved the purchase of potentially unlimited amounts of sovereign bonds on secondary markets. Effectively, this allowed the ECB to act as a lender of last resort to distressed Eurozone Member States despite this being expressly forbidden by the Treaties. If the introduction of the programme was nevertheless necessary, it revealed that the Treaties were no longer an adequate basis for the authorisation of the ECB's exercise of governmental powers. As such, the ECB's claim to legitimate authority could no longer be purely 'legal.' It had to become 'political.' What the OMT programme revealed was thus that the necessity of 'preserving the euro' introduced a 'necessity' of a different order: that of reimagining the foundation of the ECB's claim to exercise legitimate governmental authority. The second section, then, addresses how the ECB grappled with this problem and what this grappling can tell us about the relationship between emergency politics, law and democratic legitimacy.

\section{THE ECB'S EMERGENCY POLITICS}

In July 2012, at the height of the Eurocrisis, Mario Draghi (2012) announced that the ECB was 'ready to do whatever it takes to preserve the euro.' This statement, backed up 
with the announcement of the OMT programme in September 2012 (ECB, 2012a), is widely understood to have 'saved the euro' (see, e.g., Habermas, 2015; Schulz, 2015). It marked a turning point in the Crisis by 'reducing concerns about the materialisation of destructive scenarios' (Draghi and Constâncio, 2012a). It calmed the markets enough for other crisis measures to be put to work (see, e.g., Baldwin et al, 2015; De Grauwe, 2013; De Grauwe and Ji, 2013; Altavilla et al, 2014; Saka et al, 2015).

The situation at the time was, roughly, that the revelation of the depth of Greece's financial troubles in 2009-10 had led to widespread fears of contagion (from state to state and states to banks). This, in turn, had led to a 'flight to safety': investors sold off risky assets (including Spanish, Portuguese, Italian and Irish government bonds) and invested in safe ones (mainly German and French). As a result, the yield spread on Eurozone government bonds grew significantly. This development was interpreted to be the result of markets pricing in risk premia associated with 'fears of the reversibility of the euro' (ECB, 2012b, p. 5). The underlying market assumption was that under intense stress, monetary sovereignty would revert back to the Member States. There was, it seemed, no unified and effective authority able to secure the integrity and survival of the euro.

The divergence in the quality of some of the fundamental financial market assets resulted in a fragmentation of European credit markets, with the effect that credit conditions varied considerably across the Eurozone. For exposed Member States, the rising costs of government debt threatened to introduce a liquidity crisis that might, in the final instance, result in insolvency and default with unforeseeable and potentially catastrophic consequences for banks, businesses and consumers across Europe (see De Grauwe, 2013; Szczerbowicz, 2015). The euro was, in other words, in an existential crisis and neither the ECB's ordinary tools nor its existing unconventional measures had proven adequate to overcome it. 
The political significance of the euro's crisis is captured in Merkel's famous 2011 declaration that 'if the euro fails, Europe fails.' The fate of European integration rested on the survival of its most visible symbol. It was against the background of such strong political commitments that Draghi delivered his 2012 speech in London. In front of an audience of representatives of the market forces threatening to tear the Eurozone apart, Draghi asserted that there was indeed political authority willing and able to safeguard the euro. Those fearing the reversibility of the euro underestimated the 'amount of political capital that is being invested in the euro.' The euro might not have $a$ sovereign, but it was not without the sovereign authority that a currency seems to need (see Aglietta and Orléan, 1998; Aglietta and Mojon, 2012; Goodhart, 1998; Mundell, 2002). On the basis of this affirmation of political will, Draghi (2012) declared: 'the euro is irreversible.'

A declaration of political will, however, was insufficient in and of itself. It had to manifest itself, according to Draghi (2012), 'in more Europe,' meaning that in the future, 'much more of what is national sovereignty is going to be exercised at supranational level.' Future reforms, however, are of little consequence in an existential crisis in the present. Decisive governmental action is therefore needed in order to correct the market's misconception that the euro is about to collapse before this conception becomes selffulfilling (see also Draghi and Constâncio, 2012b). As such: 'Within our mandate, the ECB is ready to do whatever it takes to preserve the euro' (Draghi, 2012).

\section{The Ambiguous Authority Claim of 'Whatever It Takes'}

In terms of authority claims, Draghi's London speech was fraught with ambiguity and raised questions about the relationship between the measure in question and the ECB's legal mandate. Such questions remained unresolved following the actual announcement of the OMT programme in September (ECB, 2012a). Draghi justified his commitment by invoking a political dedication to institutional reforms of the Eurozone. That is, he 
justified the ECB's actions with reference to future changes to the legal foundations of governmental authority. In terms of justificatory logic, such teleological claims to authority can legitimise action in the present but their relation to the legal status quo is problematic. This is because action in the present is not justified solely on the basis of a strict reading of the existing law, but on the basis of an inherently contestable interpretation of what the objectives of the law are (see Tuori, 2012; Craig, 2013). In Draghi's speech, furthermore, action in the present was justified with reference to a political will for a legal order that was yet to come. The conditions necessary for the realisation of that future order (the preservation of the euro), in turn, could only be secured by the act in question. Thus, while the emphasis on political will and the dedication to decisive action that this entails was crucial in the context of seeking to re-establish market confidence in the euro, it was not clear that the act in question was authorised within the existing legal framework.

Invoking the mandate was a way of seeking to inscribe the act in question within the already existing order. But the ECB's concrete references to the legal mandate were vague. In the press conference announcing it, the OMT programme was presented as enabling the ECB to provide a 'fully effective backstop to avoid destructive scenarios with potentially severe challenges for price stability in the euro area' (Draghi and Constâncio, 2012a). Following this description of the objective of OMTs in the language of lending of last resort, however, was a sequence of unelaborated assertions: 'we act strictly within our mandate to maintain price stability over the medium term; we act independently in determining monetary policy; and the euro is irreversible.' When a journalist challenged Draghi on what gave him the 'democratic legitimation, the authority to say' that the euro is irreversible, Draghi simply asserted the ECB's general fidelity to 
the mandate and the circular argument that 'the euro is irreversible. So unfounded fears of reversibility are just what they are: unfounded fears.'

Draghi's evasive response to the question of authority reflects the ambiguity and indeterminacy of the mandate itself. While the survival of the euro is, of course, a precondition for realising the ECB's mandate of price stability, the mandate also contains a number of positive legal constraints on the ECB's powers. The mandate is thus ambiguous to the extent that there is a conflict between realising the objective or telos of the mandate (price stability) and respecting the letter of the law. In cases of conflict, the question is how to overcome the legal indeterminacy and determine which aspect of the mandate is to be prioritised and how any given prioritisation is authorised.

\section{The Questionable Legality of the OMT Programme}

The OMT programme was a promise that the ECB would, if necessary and subject to conditionality, buy unlimited amounts of government bonds of distressed Member States in secondary markets (ECB, 2012a). As such, it allowed the ECB to become the de facto lender of last resort to Eurozone governments (De Grauwe, 2013; Winkler, 2015; Baldwin et al, 2015). This promise re-established a functioning market for the bonds in question and the programme had never to be triggered; it worked its 'magic' without ever being activated (Giavazzi et al, 2013; De Grauwe and Ji 2013; Saka et al, 2015). Its inclusion in the ECB's arsenal was enough to reassure the markets.

The problem was that the prevalent understanding of article 123 of the Treaty on the Functioning of the European Union (TFEU) - the 'no monetary financing' clause precluded such lending of last resort (Beukers, 2013; Borger, 2016). Additionally, while the irreversibility of the euro was a crucial justification for the OMT programme as an emergency measure, it was not clear that the ECB was authorised to make such a declaration. Finally, seeing that debt sustainability is a fiscal, not monetary, task and the 
responsibility of the Member States according to the Treaties, the OMT programme was challenged on the grounds that it violated the division of competences between the ECB and the Member States (Craig and Markakis, 2016).

In the Gauweiler case at the German Federal Constitutional Court (GFCC), the claimants - who counted conservative politicians such as Peter Gauweiler alongside journalists, economists and the left-wing political party Die Linke - synthesised these concerns. By transforming itself into a lender of last resort for Member States with the OMT programme, they argued, the ECB's infringed, among other things, on the German people's sovereign right to decide on what powers to delegate to European institutions (see GFCC, 2014b; Cruz Villalón, 2015, §7). In referring the question to the ECJ, the GFCC indicated that unless the ECJ imposed significant limitations on the programme, it was inclined to agree with the complainants. It suggested that the ECB had committed an ultra vires act amounting to a 'unilateral usurpation of powers' (GFCC, 2014a). The ECB had acted as if it could unilaterally alter the legal framework within which it operates; it acted as if it had usurped the German people's - and, by extension, the European peoples' - sovereign prerogative (GFCC, 2016).

\section{Emergency Politics and the Law}

The ECJ rejected this line of reasoning and ruled that the OMT programme was in conformity with EU law. Whether the ECJ was right or wrong in doing so, however, is irrelevant for the present purposes. It is, rather, the very fact of the OMT programme's questionable or ambiguous legality that is of interest to this article. It is this that introduces the question of political authority into the problematic relationship between emergency politics and the law.

Emergency politics as a modality of governing stems from the concern that in an existential crisis the strict observance of the letter of law might place the legal order as a 
whole in jeopardy (see Ferejohn and Pasquino, 2004; Agamben, 2005). As Rousseau (2012, p. 118) put it, 'The inflexibility of Laws, which prevents them from bending to events, can in certain cases render them harmful, so that they can bring about the downfall of the State at a time of crisis. ${ }^{2}$ As such, the existential crisis may demand measures that are neither, strictly speaking, legal nor illegal. They are not legal because they are not provided for and may even be explicitly forbidden by the law. But they are not illegal because they are intended to ensure the conditions necessary for realising the law.

The notion of existential crisis was crucial in the Advocate General's opinion in the Gauweiler case: the situation in the summer of 2012 was 'exceptional' and raised doubts about 'whether the euro could survive' (Cruz Villalón, 2015, §3). As such, the ECJ 'is confronted with the difficulties which extraordinary circumstances have long presented for public law' (Cruz Villalón, 2015, §7). Given the extraordinary circumstances, he advocates an interpretation of the Treaties that allows the ECB 'to do what has to be done' (Cruz Villalón, 2015, §7). This means that the ECB is to be afforded 'broad discretion' when it comes to defining the scope of monetary policy (Cruz Villalón, $2015, \S \S 100,103,111$; see also ECJ, 2015, §75), assessing the proportionality of the programme (Cruz Villalón, 2015, §187; see also ECJ, 2015, §§68-75), and 'with regard to the precise definition' of what constitutes secondary market purchases (Cruz Villalón, 2015, §253; see also ECJ, 2015. §§106-108). The ECB was, in other words, to be afforded

\footnotetext{
${ }^{2}$ In the wake of the Eurocrisis, several studies have examined the question of emergency measures bending the law of the Treaties (see, e.g., Beukers, 2013; Beukers et al, 2017; Tuori and Tuori, 2014; Hinarejos, 2015; Ioannidis, 2016). What such studies to a large extent share is the notion that 'euro-crisis law' has not bent back, so to speak, but 'become simply the macroeconomic law of the EU' (Beukers et al, 2017, p. 1).
} 
'broad discretion' on some of the most contentious issues in the Gauweiler case (compare ECB, 2012a, and GFCC, 2014b).

The ECJ (2015, §68) accepted and incorporated the Advocate General's conception of the ECB's 'broad discretion' and justified it on the basis that the ECB 'is required, when it prepares and implements [a programme such as OMT,] to make choices of a technical nature and to undertake forecasts and complex assessments.' This, in turn, means that 'the courts must exercise a considerable degree of caution when reviewing the ECB 's activity' (CJEU, 2015, emphasis added). The ECB's 'broad discretion' is based on its technical 'expertise and experience' and unless 'a manifest error of assessment' can be shown, judicial scrutiny of its actions ought to be limited (ECJ, 2015, §§74-75; CJEU, 2015; see also Cruz Villalón, 2015, §§138, 187). To exaggerate but a bit: unless it is plain for all to see that the ECB's assessment of the situation and its mandate is idiotic, one must accept it as valid and, as it were, beyond the authority of courts to challenge. The $\mathrm{ECB}$, in other words, is to be afforded 'broad discretion to decide in and on the state of exception,' to paraphrase Carl Schmitt (2005). In fact, evaluating whether its means violate the mandate is not merely impossible for anyone but the ECB itself, it might even jeopardise the survival of the euro, if not the EU as a whole (Borger, 2016, p. 139).

Due to the technical complexity of monetary policy, on the one hand, and the potentially catastrophic consequences of mistakenly annulling its acts, on the other, the ECB's discretion is thus essentially legally unreviewable according to the body primarily responsible for such reviews (see CJEU, 2015; ECJ, 2015, §§68, 70; see also Borger, 2016). Although in many ways a troubling notion derived from the emergency political tradition of (constitutional) dictatorship (Rossiter, 1948; Ferejohn and Pasquino, 2004; Agamben, 2005; Schmitt, 2014), 'unreviewable discretion' is not an uncommon feature of contemporary governmental practice. As Levinson and Balkin (2010, p. 1807) note, 
"many elements of republican government could be seen as "dictatorial" to the extent that they endow government actors with essentially unreviewable discretion to set policy and execute it immediately with the force of law.' 3 What makes such discretion 'unreviewable' is that it affects agents' behaviour instantly and without mediation. Following its announcement or enactment, furthermore, the discretionary measure is all but impossible to countermand. Once the effects have manifested themselves it becomes either futile or dangerous to call the measure into question by legal means.

The impossibility or danger of judicial review with respect to discretionary measures such as the OMT programme does not mean that they are necessarily democratically illegitimate. It does, however, increase the importance of political accountability (Levinson and Balkin, 2010, p. 1858). In other words, if the legitimacy of a measure cannot be determined unequivocally be legal means, it must be determined politically.

\section{THE PEOPLE OF EUROPE AS A FOUNDATION OF AUTHORITY}

The notion of 'broad discretion' has been fully incorporated into the ECB's vocabulary for describing itself and its prerogatives following, and with reference to, the ECJ's ruling (see, e.g., ECB, 2015, 2017a; Draghi, 2015; Cœuré, 2015; Praet, 2015; Mersch, 2016, 2017; Gren, 2018). ${ }^{4}$ However, while the ECJ justified the ECB's broad discretion legally

${ }^{3}$ Levinson and Balkin use the US Federal Reserve's emergency measures during the Financial Crisis as an example.

${ }^{4}$ The only direct citation from the ruling in ECB's press release taking note of it concerns the ECB's "“broad discretion" when it "prepares and implements an open market operations programme" as it needs "to make choices of a technical nature and undertake forecasts and 
and with reference to the ECB's unrivalled technical expertise within its field, the ECB itself has sought an additional, more political justification. As Draghi (2016) put it in the European Parliament (EP), the 'political commitment underpinning our single currency has been strongly reaffirmed during the crisis.' The counterpart to the broad and unreviewable discretion of the ECB is thus to be found in political will. The question, then, is how and in what form this political will manifests itself.

\section{Reimagining the ECB's Foundation of Authority}

The logic informing the increased importance of political will in the context of emergency measures such as the OMT programme was spelled out by Cœuré $\left(2012^{5}\right)$ in a talk on 'how to interpret' the OMT decision shortly after it was announced. In line with the above, Cœuré notes that in an extraordinary situation that demands unconventional measures, the 'permanent assessment of the central bank's performance against its mandate and strategy ... has become very complicated.' This complexity means that accountability to 'les Européens' ('the people of Europe' in ECB's translation) and 'les citoyens de l'Union européenne' ('the people of the European Union' in ECB's translation) takes on an increased importance. It cannot merely take the traditional form of reporting to the EP on how the ECB is realising its objectives. Referring to an article by Habermas, Bofinger and Nida-Rümelin (2012), Cœuré (2012) suggests that a stronger form of accountability is needed:

complex assessments"' (ECB, 2015). I have not been able to find references to "broad discretion' in ECB discourses prior to the ruling.

${ }^{5}$ In citing from this speech, I have altered the English translation slightly on the basis of the French original. Both versions are included in the bibliography. 
Once we create scope in the euro area for policies that result in redistributive effects across national boundaries ... European legislators [le législateur européen, in Cœuré's original French, ein europäischer Gesetzgeber, in the original German article] who represent[s] the people [représentant le peuple in the French, die Bürger ... vertritt in the German] must be able to decide and vote on these policies. I tend to sympathise with this view.

The notion of accountability that Cœure envisions is one that affirms the need to empower a European-level institution to make authoritative political decisions based on a political mandate from the people (le peuple) as the foundational political subject. This, furthermore, is not merely a hope for the future but is a necessity arising from the Crisis and what it revealed about the governmental structure of the Eurozone:

The notion that the euro is a currency without a state is ... misguided. The euro is the currency of a state - but it's a state whose decision-making structure is not yet clearly defined ... The ECB is independent and fully accountable, but it needs clearly identifiable and fully empowered interlocutors (Cœuré, 2012, translation altered by author).

The statement that the euro is the currency of a state should, of course, not be read as an accurate description of reality. It expresses, rather, a perceived need for institutional means of generating politically authoritative decisions within the EU's governmental structure at the level at which the ECB operates. In this regard it is notable that Couré (2012) is not simply citing 'Habermas and his co-authors' in a translated form. He alters the original phrasing from the plural to the singular and from the citizens to the people (from die Bürger to le peuple). In doing so, he invokes the traditional state-theoretical basis of authority in a unitary popular sovereign and brings it, through representation in a legislature, out of the Treaty-making moment of the past and into the present. 
Reimagining the ECB's foundation of authority in the context of the Crisis thus involves two elements, according to Cœuré: a unitary subject of authorisation and the representation of this subject in a body able to express political will in the present. This reimagining is not limited to Cœuré's speech but is, for one, manifest in a comprehensive reformulation of the ECB's self-description on its website after the ECJ's Gauweiler ruling. Most notably, perhaps, the ECB's mission statement was, in February 2016, changed from 'Our mission is to serve Europe's citizens' ${ }^{6}$ to 'Our mission is to serve the people of Europe. ${ }^{7}$ Similarly, the brief note on accountability on the same page was also changed from 'Accountability towards European citizens' and 'The ECB works for the citizens of Europe" ${ }^{8}$ to 'Accountability towards the people of Europe' and 'We work for the people of Europe.' 9

The notion of a people of Europe as the foundation of the euro and the ECB's authority is reflected in a number of public appearances by ECB officials (see, e.g., Draghi 2016a, 2016b, 2016c, 2017, 2018a, 2018b, 2018c, 2018d, 2018e, 2018f; Cœuré, 2012, 2013, 2016, 2018; Mersch, 2017b; Constâncio, 2017; Lautenschläger 2017; Angeloni, 2019). Even so, the changes on the website are, of course, inconclusive in and of themselves. However, being unnecessary, they are notable and beg questioning: why

${ }^{6}$ From the web page 'About,' as archived on 8 February 2016, emphasis added, available at: http://web.archive.org/web/20160208055206/https://www.ecb.europa.eu/ecb/html/index.en.h $\underline{\text { tml }}$ [accessed 20 May 2019]

${ }^{7}$ From the current web page 'About,' emphasis added, available at: https://www.ecb.europa.eu/ecb/html/index.en.html [accessed 20 May 2019].

${ }^{8}$ See note 6.

${ }^{9}$ See note 7. The ECB's independence is also presented as being intended ' $[\mathrm{t}] \mathrm{o}$ ensure the ECB acts in the best interest of the European people' (ECB, 2017b). 
replace references to the perfectly uncontroversial citizens with references to the much more contentious and multivalent the people? Why reconstruct the political subject, the 'master' that the ECB 'serves,' in another name?

\section{The Citizens and the People in EU Law and Political Theory}

The precise motivation for the change is difficult to gauge. It is, however, notable that the ECB now - in line with Cœuré's notion of a euro-state - characterises itself in a manner similar to central banks within consolidated (federal) states. The US Fed, for instance, refers to 'the nation' ${ }^{10}$ and the Bank of England refers to 'the people.' ${ }^{11}$ In political discourse more broadly, invocations of the people or nation as a collective identity always entail elements of simplification, reduction and aspiration. As Laclau (2005, p. 100) put it, 'the symbolic unification of the group around individuality ... is inherent to the formation of a "people." Invoking the people is thus a (populist) means of giving discursive 'unity to a heterogeneous ensemble' (Laclau, 2005, p. 108), to give unity to diversity, as it were. The people, in other words, is a discursive political resource invoked to justify claims to authority (see Canovan, 2005).

The people, however, is not only a powerful rhetorical trope. It also carries a distinct legal-political meaning, which informs the distinction between the citizen and the people in the EU Treaties as well as the ECB's pre-crisis conception of its foundation of authority. Indeed, the significance of the ECB's discursive change is perhaps best attested to by the absence of the notion of a people of Europe in the Treaties.

The EU Treaties are careful to only use the term people when referring to a specific category of people (see, e.g., article 78.2(g) TFEU on asylum seekers and article

\footnotetext{
${ }^{10}$ From https://www.federalreserve.gov/ (accessed 20 May 2019).

${ }^{11}$ From https://www.bankofengland.co.uk/ (accessed 20 May 2019).
} 
165.2 TFEU on young people). More significantly in terms of the underlying political theory, the Treaties invoke the term in the plural: 'ever closer union among the peoples of Europe' (Preamble TEU and TFEU, emphasis added), 'DESIRING to deepen the solidarity between their peoples' (Preamble TEU, emphasis added), and 'The Union's aim is to promote peace, its values and the well-being of its peoples' (Article 2 TEU, emphasis added). The Treaties thereby reflect a particular legal-political meaning of peoples or the people in the Treaties. This meaning was expressed most clearly in the Preamble to the Treaty of Rome, which called 'upon the other peoples of Europe (les autres peuples de l'Europeldie anderen Völker Europas) who share their ideal to join in their efforts.' It is the peoples of Europe - not the states or governments - that are called upon to express their political will to associate themselves with the project. But they do so individually as distinct peoples and do not give up their individual peoplehoods to become a people in (the ratification of) subsequent treaties.

Since the Maastricht Treaty, in contrast, EU citizenship is firmly established in EU law: 'Every national of a Member State shall be a citizen of the Union. Citizenship of the Union shall be additional to and not replace national citizenship' (articles 9 TEU and 20 TFEU). The people, in the legal-political sense, thus denotes the foundational political subject of each Member State, while citizenship denotes a body of rights that individuals enjoy by virtue of belonging to the EU as a community of communities. European citizenship is thus a legal category and a product of a political decision by the peoples of Europe, who are, collectively but separately, the foundational subjects of the European integration process (as well as of their respective states). In an early formulation of its claim to authority and 'input legitimacy,' the ECB (2002, p. 46, emphasis added) reflected this notion: 'all power emanates from the people' and the ECB is a product of 'the sovereign decision of the peoples of Europe.' 
The different meanings of the people and citizens are equally evident in the constitutional (case) law of a number of Member States. The Preamble of the German Basic Law, for instance, asserts that 'the German people [das Deutsche Volk] has given itself this Basic Law by virtue of its constituent power' and article 20(2) states that 'All state power is derived from the people' (my translations). The notion of a unitary people, however, is deeply controversial when it comes to the EU and on several occasions the GFCC has asserted that there is no people of Europe, no European demos; 'only the peoples of the Member States can dispose of their respective constituent powers and of the sovereignty of the state.' Thus, '[w]ithout the expressly declared will of the people, the elected bodies are not competent to create a new subject of legitimation, or to delegitimise the existing ones, in the constitutional areas of their states.' 12 The GFCC, however, considered EU citizenship unproblematic precisely because it did not create such a subject. It was clear from the Treaties that 'the use of the term "citizens of the Union"' was not intended "to create an independent personal subject of legitimation at European level' (Lisbon Judgement \$349, emphasis added).

The distinction between citizens and the people on which both the EU Treaties and the GFCC's reasoning are based is to a significant extent derived from social contract theory. It reflects Hobbes' (1998, p. 137, all emphases in original) notion that 'A people is a single entity, with a single will; you can attribute an act to it.' In contrast, 'the citizens, i.e. the subjects, are a crowd' (Hobbes, 1998, p. 137). Citizens thus lack a unified political

${ }^{12}$ See the GFCC's Lisbon Judgement of 30 June 2009, §347; see also Maastricht Decision of 12 October 1993. The notion of the Member State peoples constraining their respective governments and parliaments when it comes to European integration, informs the GFCC's ultra vires review of acts of EU institutions, which it performed in Gauweiler as well as in its initial deliberations in the Weiss case relating to the ECB's QE programme. 
agency (see Loughlin, 2003, p. 56) and can only forge a common will out of their multiplicity of opinions through submitting their individual "will to the will of the majority ... as if each man said: I transfer my right to the people ... on the condition that you transfer your right to the people' (Hobbes, 1998, p. 95). The political agency of citizens is thus realised only through political representation in an institution 'whose will is the will of all the citizens' and which 'has sovereign power' (Hobbes, 1998, p. 94). 'In every commonwealth,' then, 'the People Reigns ... for the people wills through the will of' the sovereign body, whether King or Assembly (Hobbes, 1998, p. 137).

In Hobbes, the people is thus an 'artificial' person that authorises all acts of sovereign power. Citizen is the legal term for individuals subject to the constituted order. The concrete meaning of citizenship is thereby bound to the particular legal order established by the people, but the people cannot be bound by the citizens. The people is a creative political subject bound only by its own volition - and therefore in fact not bound at all (Hobbes, 1998, p. 95) - whereas the citizens is the name for the aggregation of individuals subject to the will of the people.

The active power of the people in government is exhausted in the original transfer of powers to the Hobbesian sovereign. Subsequent social contract thinkers, however, conceived for the people a more active role. Locke (1988, p. 427, emphases in original), for instance, reserved for the people the right to 'Judge' the conduct of political officeholders. This right was based on the logic that if the people holds the power to name an officer, it must 'have still a Power to discard him, when he fails in his Trust.' Like in Hobbes, individuals give up their individual rights and powers in the moment of the social contract. But instead of transferring those rights and powers directly to the sovereign, they constitute an intermediate body between the mass of individuals and the sovereign: 'Society.' In line with the Hobbesian logic, then, 'when the Society hath placed the 
Legislative in any Assembly of Men ... the Legislative can never revert to the People whilst Government lasts' (Locke, 1988, p. 428). However, the people retain the 'right to act as Supreme, and continue the Legislative in themselves, or erect a new Form, or under the old form place it in new hands' if its deputies fail in their duties (Locke, 1988, p. 428). The people thus retains the highest political power, the power to judge, depose and replace the holders of sovereign power, but it does not govern (see also Tuck, 2016). Government and sovereignty are thereby differentiated and separated.

Rousseau retained the Hobbesian/Lockean conception of the social contract as an 'act of association [that] produces a corporate and collective body ... a body that receives from this very act its unity, its common self, its life and its will' (Rousseau, 2012, p. 20). The associates, in turn, 'collectively take the name of people' and 'are called Citizens as participants in the sovereign authority' (Rousseau, 2012, p. 21). The collective body of citizens constitutes the people as a unitary actor, the sovereign body that wills, and as particular persons with particular wills they participate (or not) in the affairs of state as citizens. The citizen has a particular will, the people always represents the general will.

In contrast to Hobbes, however, Rousseau presents a more organic notion of popular sovereignty: 'sovereignty, being merely the exercise of the general will, can never be alienated ... the sovereign, which is merely a collective being, can be represented only by itself; power can indeed be transferred, but not will' (Rousseau, 2012, p. 29). The Hobbesian notion of an irreversible transfer of sovereignty from the people to a sovereign office is thus 'absurd' to Rousseau:

it is inherent in no will to consent to anything opposed to the welfare of the being that does the willing. Hence, if the people promises simply to obey, by that act it dissolves itself and loses its quality as a people (Rousseau, 2012, p. 30).

This, however, 
does not at all mean that the orders of rulers cannot be taken as general wills, so long as the Sovereign, being free to oppose them, does not do so. In such a case, the agreement of the people must be presumed from the universal silence' (Rousseau, 2012, p. 30, emphasis added).

The people's will thus informs all acts of government but does not have to express itself positively in order to do so; its consent can be deduced from its silence. For an act of government to be legitimate and representative of the people's will, it needs only tacit consent. By fusing government and sovereign will, Rousseau's organic notion of popular sovereignty challenges Locke's notion of separating government and sovereignty. But it does so by taking Locke's notion of the people's right to judge to its logical conclusion: the absence of a negative judgement must be understood as an expression of consent. Rousseau thereby introduces a conception of popular sovereignty that allows for more flexibility in the exercise of governmental power. He introduces a conception of government that is no longer dependent on pre-existing expressions of the people's will in (constitutional) law.

\section{The Foundational Meaning of the People of Europe in ECB discourses}

The ECB traditionally conceived of its mandate as being based on the sovereign decision of the peoples of Europe (ECB, 2002) in a 'democratic naissance' (Zilioli and Selmayr, 2001, p. 49). Within the constituted order, however, the body of European citizens had no right to alter the mandate or sanction the ECB for failing in the performance of its duties (see, e.g., Smits, 1997, p. 500; Zilioli and Selmayr, 2001, p. 48; ECB, 2002, p. 47; Issing, 2002, p. 43). The logic of the continued sovereignty of the peoples of Europe as separate political subjects thereby informed the ECB's constitutionalised independence. The ECB's mandate would be unalterable in the absence of a democratic 're-naissance,' so to speak, because no unified political subject with the authority to change the 
fundamental constitutional distribution and limitation of powers was established. Limiting democratic input legitimacy to the founding moment would thus secure the ECB's independence from political control. In short, the peoples of Europe were the constituent power but within the constituted order the European citizens would have no institutionalised means of judging the ECB's conduct or altering its mandate because they did not become a European people but remained a crowd of individuals.

The emphasis on the constituent moment at the expense of the continuous possibility of political control would also, however, mean that the ECB would have to govern strictly in accordance with 'a clearly defined mandate.' In order to remain democratically legitimate, it would have to act 'within the limits and the powers conferred upon it by the Treaty' (ECB, 2002, p. 46). This would represent 'a constraint on the discretionary exercise of power ... by the central bank' and the 'closest realistic and credible approximation to a literal "rule of law"' (Issing, 2002, p. 28).

This conception of the ECB's foundation of authority used to inform the ECB's own rendition of its accountability. The ECB, according to its website, was independent 'in carrying out its mandate and tasks,' a principle 'firmly grounded in economic theory and empirical evidence.' ${ }^{13}$ Accountability was 'an important counterpart' to such independence. It was, however, a quite thin form of accountability (see, e.g., Amtenbrink, 2002; Curtin, 2017), consisting mainly of reporting to the EP and public communications intended to explain and justify 'to the European citizens and their elected representatives how [the ECB] uses the powers and prerogatives it has been entrusted' (ECB, 2002, p.

${ }^{13}$ From the web page 'Accountability,' as archived on 9 March 2016, emphasis added, available at: http://web.archive.org/web/20160309125918/http://www.ecb.europa.eu/ecb/orga/accountabil ity/html/index.en.html [accessed 22 May 2019]. 
46). Besides this, it offered few clues as to what powers 'the European citizens and their elected representatives' might have vis-à-vis the ECB. They might have the power to ask questions, but in accordance with the Hobbesian logic, they did not hold the power to demand answers. They did certainly not have the power to authorise or veto specific measures.

In the context of the Crisis, the ECB's understanding of its own accountability has changed towards a more Lockean, even Rousseauian conception. In line with the notion of 'broad discretion' discussed above, the ECB has altered its note on accountability on its website. The ECB is now 'an independent institution which has discretion to use its instruments as necessary to carry out its tasks and fulfil its mandate. Accountability is the necessary counterpart to that independence.' ${ }^{14}$ The reference to 'discretion' is notably absent from both the prior formulation on the website and the $2002 \mathrm{ECB}$ article on accountability cited there (as well as above). In the current version, discretion is presented in the context of necessity: the necessity associated with carrying out the tasks entrusted to the ECB and, given this discretion, the necessity of accountability.

Like discretion, the notion of necessity is absent from previous accounts. With its inclusion, the emergency political vocabulary - necessitas non habet legem (Agamben, 2005; Ferejohn and Pasquino, 2004) - has made its way into the ECB's discourse on its democratic accountability. Alongside 'broad discretion,' which as a modality of decision making is closely associated with emergency rule (Levinson and Balkin, 2010; White, 2015), the emphasis on necessity introduces a stronger notion of accountability:

\footnotetext{
${ }^{14}$ From the current web page 'Accountability,' emphasis added, available at: https://www.ecb.europa.eu/ecb/orga/accountability/html/index.en.html [accessed 21 May 2019].
} 
The ECB explains its decisions and underlying reasoning to EU citizens and their elected representatives. On this basis, they can then form a judgement on the ECB's performance against its objectives. ${ }^{15}$

The ECB's reporting and public communications thus serve 'to make its decisions more transparent to the general public so that EU citizens are better able to understand and judge them' (Fraccaroli et al., 2018, emphasis added).

The language of judgement is strong; particularly compared with earlier formulations. It suggests that EU citizens are able to authorise or veto particular acts of discretion through (their representation in) the EP. For the ECB, then, the EP becomes 'the channel through which we can explain to the people of Europe the reasons for our decisions' and the ECB and the EP 'have responded to the demand for stronger scrutiny that arose during the crisis and have ensured a high degree of accountability throughout it' (Draghi, 2018a, emphases added). This notion of accountability downplays the element of ensuring that the ECB acts strictly within 'the limits and powers conferred upon it' and emphasises the more teleological notion of the ECB being able to realise its 'objectives.' It is still unclear what exactly a negative judgement would entail. However, the very notion indicates that the ECB assigns some kind of authority, if not coercive power, to the evaluation of its actions by 'the direct representatives of the people of Europe' (Draghi, 2016a, emphasis added).

Accountability as judgement at the same time introduces the Rousseauian potential for a higher degree of open-endedness and flexibility in the ECB's governmental activities. As long as the EP, which is 'an attentive interpreter of the demands of European citizens' (Draghi, 2019), does not judge the ECB's discretionary activities negatively,

\footnotetext{
${ }^{15}$ See note 14 , emphasis added.
} 
they must be regarded as democratically legitimate. As such, Yves Mersch (2017, p. 20), Member of the ECB's Executive Board, has argued that ' $[t]$ he development of the ECB's accountability practices has ensured continued effective scrutiny, even as the ECB's role expanded as a result of the crisis.' According to Yves Mersch (2017, p. 18, emphasis added), the ECB-EP relationship 'provides an example of how sovereignty and accountability can ... be aligned when transferring a competence to European level' and constitutes 'a true reflection of a functioning democracy' by aligning 'liability and control ... at European level' (Mersch, 2017, p. 20, emphasis added). The ECB, after all, 'ultimately acts on behalf of the people and for the people' (Mersch, 2017, p. 13).

What the ECB, and the EU more broadly, 'gives to the people of Europe,' is thus 'a way of sustaining an open international order while also bending its outcomes to their will' (Cœuré, 2018, emphases added). It offers, according to Draghi (2013), 'the ability to deliver in practice the essential services that people expect from government.' This, in turn, is what 'defines, and legitimises, sovereignty.' In the absence of such capacity, '[a] sovereign ... would be sovereign only in name.' For the peoples of Europe to retain sovereignty, then, they must become the people of Europe; the 'time for European sovereignty has come' (Juncker, 2018, p. 5).

The stronger notion of democratic accountability and scrutiny that accompanies the ECB's expanded mandate following the crisis, then, reimagines the ECB's authority as being based on the unitary people of Europe. In doing so, it reimagines the European citizens as participants in the exercise of sovereign authority at the European level by granting them the Lockean right to judge (even control) governmental acts. The foundation of the ECB's authority is thereby moved from a rigid social contract based on a past expression of the multiple sovereign wills of the peoples of Europe to a more organic expression of the will of the people of Europe in the present. The unitary notion 
of the people thus both grounds and is derived from the ECB's (and thus the EU's) capacity to exercise effective sovereignty by 'bending outcomes' to political will.

The reimagining of the ECB's foundation of authority reflects the emergency political notion that '[i]f the exercise of emergency powers undercuts or substantially modifies the legal order or the constitution itself ... it is no longer properly an exercise of an emergency power at all but is an exercise of constituent power' (Ferejohn and Pasquino, 2004, p. 223). Accordingly, if ECB acts have changed one of the basic elements of the legal ordering of Eurozone governance, its foundation of authority must change with it. However, because of the continued absence of formal mechanisms for sanctioning the ECB for transgressions, the political authorisation must, in the absence of a democratic re-naissance, take the Rousseauian form of the people's will manifesting itself primarily through the people's (silent) consent to governmental acts. During the crisis, then, the people's support for the ECB, expressed positively by the EP and/or negatively by the absence of effective expressions of political will against the ECB's acts, has ensured that the ECB 'could legitimately be independent in carrying out its monetary policy' (Draghi, 2019). The EP's support, furthermore, was 'sincere' and 'important' because 'it built on the voice of European citizens and ... helped the ECB through the many difficult times of the past years' (Draghi, 2019). The EP as the representative of the people of Europe, in other words, legitimised the ECB's actions and provided the political foundation for the ECB's governmental capacity in the future.

\section{CONCLUSION}

The 'no demos thesis' of the GFCC, like the ECB's 'sovereign decision of the peoples of Europe,' relies on the notion that collective expressions of political will precede, ground and constrain the exercise of governmental powers. Governmental authority, accordingly, rests on a foundation laid by an unambiguous proclamation by the constituent power(s) 
of We the People(s) in the past. In the existential crisis, however, this authorisation sequence tends to be suspended or reversed. Political authorisation is reconstructed after governmental power is already being exercised as if the foundation of its authority were in place (see Ioannidis, 2016; Ackerman, 2000).

In the Eurocrisis, the ECB was faced with the problem that a reliance on a strict understanding of the legal mandate might have left no mandate to fulfil. To rescue the euro and its associated legal order, the ECB thus exercised 'broad' and unreviewable discretion in a manner that redefined the meaning of some of the fundamental tenets of that legal order. The appeal to the people of Europe in ECB discourses, then, assumes its significance in response to the need to reconstruct the foundation of the authority of such governmental acts.

By reimagining its foundation of authority as being based on the unitary European people, the ECB has introduced the notion of an organic link between governmental power and the sovereign people, which can act as judge and (silently) authorise new governmental practices in the present. Following the Rousseauian logic, this allows the ECB (and the Eurozone in general) a greater flexibility to redefine its governing philosophy in response to socio-economic developments than would the strict observance of the letter of the law. It might even potentially allow for changing political and economic ideas and values to be reflected in monetary policy. The open question, then, is how to make democratic 'judgement' and 'control' meaningful and what this would mean for the ECB's independence.

The article has proceeded in an interpretative manner, using only publicly available sources. It has thus disregarded the question of the ECB's 'actual' motivation for the using the language of the people of Europe and what meaning it attributes to the notion. It has also not addressed the question of whether the notion is invoked more 
broadly in EU political discourse, has any broader social resonance, or whether it might be a form of technocratic populism responding to the rise of anti-euro populism in Europe (see Bickerton and Invernizzi Accetti, 2018). These are questions beyond the scope of this article, which will demand different methods for answering. Addressing such questions, however, might be of interest for further research, particularly if combined with the question of the audience of central bank communications (see Lohmann, 2003; Braun, 2016). To whom is the ECB speaking when it invokes the people of Europe? Cursorily, the ECB appears to invoke it in non-technical appearances before the general public and its 'intermediaries' (general media, parliamentarians, public lectures and academic conferences). Affirmations of political will such as Draghi's 'whatever it takes,' on the other hand, seem to be made before investors or the financial press. The question, then, is whether this is a general pattern. If so, how does it relate to the different registers of the central bank's communications and its attempt (or lack thereof) to balance the differing values, expectations and knowledges of the communities a central bank serves.

\section{BIBLIOGRAPHY}

Ackerman, B. (2000) We the People, Volume 2: Transformations, Cambridge, MA and London: Harvard University Press.

Agamben, G. (2005) State of Exception, Chicago, IL: Chicago University Press.

Aglietta, M. and Mojon, B. (2012) 'Central Banking,' in Berger, A.N., Molyneux, P. and Wilson, J.O.S. (eds) The Oxford Handbook of Banking, First Edition, Oxford: OUP.

Aglietta, M. and Orléan, A. (1998) La monnaie souveraine, Paris: Odile Jacob.

Altavilla, C., Giannone, D. and Lenza, M. (2014) 'The Financial and Macroeconomic Effects of OMT Announcements', ECB Working Paper Series no 1707/August.

Amtenbrink, F. (2002) 'On the Legitimacy and Democratic Accountability of the European Central Bank: Legal Arrangements and Practical Experience,' in A. 
Arnull and D. Wincott (eds), Accountability and Legitimacy in the European Union, pp. 147-163, Oxford: Oxford University Press.

Angeloni, I. (2019) 'Supervisory independence,' speech at the ECB colloquium "Challenges for Supervisors and Central Bankers”, Frankfurt am Main, 22 March, available at:

https://www.bankingsupervision.europa.eu/press/speeches/date/2019/html/ssm.sp 190322 c231d57793.en.html [accessed 22 May 2019].

Baldwin, R., Beck, T., Bénassy-Quéré, A., Blanchard, O., Corsetti, G., de Grauwe, P., den Haan, W., Giavazzi, F., Gros, D., Kalemli-Ozcan, S., Micossi, S., Papaioannou, E., Pesenti, P., Pissarides, C., Tabellini., G., and Weder di Mauro, B. (2015) 'Rebooting the Eurozone: Step 1 - agreeing a crisis narrative', Center for Economic Policy Research Policy Insight No. 85.

Beukers, T. (2013) 'The new ECB and its relationship with the eurozone Member States: Between central bank independence and central bank intervention', Common Market Law Review 50 (6): 1579-1620.

Beukers, T., De Witte, B., and Kilpatrick, C. (2017) 'Chapter 1: Constitutional change through euro-crisis law: taking stock, new perspectives and looking ahead,' in Beukers, T., De Witte, B., and Kilpatrick, C. (eds) Constitutional change through euro-crisis law, Cambridge: CUP.

Bickerton, C.J. and Invernizzi Accetti, C. (2018) “"Techno-populism” as a new party family: the case of the Five Star Movement and Podemos,' Contemporary Italian Politics, 10(2): 132-150, DOI: 10.1080/23248823.2018.1472919

Borger, V. (2016) “Case Law: A. Court of Justice: Outright Monetary Transactions and the stability mandate of the ECB: Gauweiler," Common Market Law Review 53: 139-196.

Braun, B. (2016) 'Speaking to the people? Money, trust, and central bank legitimacy in the age of quantitative easing,' Review of International Political Economy, 23(6): 1064-1092, DOI: 10.1080/09692290.2016.1252415 
Braun, B. (2017) Two sides of the same coin? Independence and Accountability of the European Central Bank, Transparency International EU, available at: https://transparency.eu/wpcontent/uploads/2017/03/TI-EU ECB Report DIGITAL.pdf (accessed 9 May 2019).

CJEU (Court of Justice of the European Union) (2015) 'According to Advocate General Cruz Villalón, the ECB's Outright Monetary Transactions programme is compatible, in principle, with the TFEU', Press release No 2/15, Luxembourg, 14 January.

Canovan, M. (2005) The People, Cambridge: Polity.

Cœuré, B. (2012) 'Restoring trust in Economic and Monetary Union', Speech at Forum Eco Libération ESCP, “Reprendre confiance en (l')Europe,” panel discussion: “L'Euro méfiance, c'est fini?", Paris, 1 December, available at: https://www.ecb.europa.eu/press/key/date/2012/html/sp121201.en.html (accessed 23 July 2018), French version available at: https://www.ecb.europa.eu/press/key/date/2012/html/sp121201.fr.html (accessed 23 July 2018).

Cœuré, B. (2013) 'Revisiting the European social contract', Speech at the European Conference at Harvard, "Europe 2.0 - Taking The Next Step," Cambridge MA, 2 March, available at: https://www.ecb.europa.eu/press/key/date/2013/html/sp130302.en.html (accessed 26 June 2018).

Cœuré, B. (2015) 'Drawing lessons from the crisis for the future of the euro area,' speech at Ambassadors Week, Paris, 27 August, available at: https://www.ecb.europa.eu/press/key/date/2015/html/sp150827.en.html (accessed 2 December 2018).

Cœuré, B. (2016) ‘Addressing Europe's economic and political challenges', introductory remarks at TUM Speakers Series/HEC Débats, Technical University of Munich, Munich, 21 November, available at: https://www.ecb.europa.eu/press/key/date/2016/html/sp161121.en.html (accessed 23 July 2018). 
Cœuré, B. (2018) 'Taking back control of globalisation: Sovereignty through European integration,' contribution to Schuman Report on Europe, 28 March, available at: https://www.ecb.europa.eu/press/inter/date/2018/html/ecb.in180328.en.html (accessed 2 December 2018).

Constâncio, V. (2017) Presentation of the ECB Annual Report 2016 to the Committee on Economic and Monetary Affairs of the European Parliament, Brussels, 10 April, available at: https://www.ecb.europa.eu/press/key/date/2017/html/sp170410.en.html (accessed 23 July 2017).

Craig, P. (2013) 'Pringle: Legal Reasoning, Text, Purpose and Teleology,' Maastricht Journal of European and Comparative Law, 20(1): 3-11. doi: 10.1177/1023263X1302000101

Craig, P. and Markakis, M. (2016) 'Gauweiler and the Legality of Outright Monetary Transactions,' European Law Review 41(1), Oxford Legal Studies Research Paper No. 5/2016.

Cruz Villalón, P. (2015) 'Opinion of Advocate General Cruz Villalón, Case C - 62/14', Luxembourg, 14 January.

Curtin, D. (2017) “"Accountable Independence” of the European Central Bank: Seeing the Logics of Transparency,' European Law Journal, 23: 28-44. doi: 10.1111/eulj.12211.

De Rynck, S. (2016) 'Banking on a union: the politics of changing eurozone banking supervision', Journal of European Public Policy 23(1): 119-135.

Draghi, M. (2012) Verbatim of the remarks at the Global Investment Conference, London, 26 July, available at: https://www.ecb.europa.eu/press/key/date/2012/html/sp120726.en.html (accessed 23 July 2018).

Draghi, M. (2013) 'Europe's pursuit of 'a more perfect Union', lecture at Harvard Kennedy School, Cambridge, MA, 9 October, available at: 
https://www.ecb.europa.eu/press/key/date/2013/html/sp131009_1.en.html (accessed 23 July 2018).

Draghi, M. (2015) 'Global and domestic inflation,' speech at Economic Club of New York, 4 December, available at: https://www.ecb.europa.eu/press/key/date/2015/html/sp151204.en.html [accessed 22 May 2019].

Draghi, M. (2016a) Hearing of the Committee on Economic and Monetary Affairs of the European Parliament, Brussels, 26 September, available at: https://www.ecb.europa.eu/press/key/date/2016/html/sp160926_2.en.html (accessed 23 July 2018).

Draghi, M. (2016b) 'Reviving the spirit of De Gasperi: working together for an effective and inclusive Union', speech at the presentation ceremony of the De Gasperi award, 13 September, available at: https://www.ecb.europa.eu/press/key/date/2016/html/sp160913.en.html [accessed 23 July 2018].

Draghi, M. (2016c) Introductory statement to the plenary debate of the European Parliament on the ECB's Annual Report 2015, Strasbourg, 21 November, available at: https://www.ecb.europa.eu/press/key/date/2016/html/sp161121_1.en.html [accessed 19 May 2019].

Draghi, M. (2017) 'Security through unity: making integration work for Europe,' speech at the joint ECB and Banka Slovenije conference on the occasion of the 10th anniversary of the adoption of the euro, Ljubljana, 2 February, available at: https://www.ecb.europa.eu/press/key/date/2017/html/sp170202.en.html [accessed 19 May 2019].

Draghi, M. (2018a) 'Hearing of the Committee on Economic and Monetary Affairs of the European Parliament', Introductory Statement at the ECON committee of the European Parliament, Brussels, 24 September, available at: 
https://www.ecb.europa.eu/press/key/date/2018/html/ecb.sp180924.en.html (accessed 15 November 2018).

Draghi, M. (2018b) ‘Europe and the euro 20 years on,' speech at Laurea Honoris Causa in Economics by University of Sant'Anna, Pisa, 15 December, available at: https://www.ecb.europa.eu/press/key/date/2018/html/ecb.sp181215.en.html [accessed 19 May 2019].

Draghi, M. (2018c) 'Exchange of views with members of the Irish Parliament,' introductory statement, House of Representatives, Dublin, Ireland, 8 November, available at: https://www.ecb.europa.eu/press/key/date/2018/html/ecb.sp181108_1.en.html [accessed 19 May 2019].

Draghi, M. (2018d) 'Risk-reducing and risk-sharing in our Monetary Union,' speech at the European University Institute, Florence, 11 May, available at: https://www.ecb.europa.eu/press/key/date/2018/html/ecb.sp180511.en.html [accessed 19 May 2019].

Draghi, M. (2018e) Hearing of the Committee on Economic and Monetary Affairs of the European Parliament, introductory Statement at the ECON committee of the European Parliament, Brussels, 26 February, available at: https://www.ecb.europa.eu/press/key/date/2018/html/ecb.sp180226_1.en.html [accessed 19 May 2019].

Draghi, M. (2018f) European Parliament plenary debate on the ECB Annual Report for 2016, introductory statement and closing remarks, Strasbourg, 5 February, available at: https://www.ecb.europa.eu/press/key/date/2018/html/ecb.sp180205.en.html [accessed 19 May 2019].

Draghi, M. (2019) Hearing of the Committee on Economic and Monetary Affairs of the European Parliament, Introductory Statement, Brussels, 28 January, available at: https://www.ecb.europa.eu/press/key/date/2019/html/ecb.sp190128 8b43137b4f.en.html [accessed 22 May 2019]. 
Draghi, M. and Constâncio, V. (2012a) Introductory statement to the press conference (with Q\&A), Brdo pri Kranju, Slovenia, 4 October, available at: https://www.ecb.europa.eu/press/pressconf/2012/html/is121004.en.html [accessed 19 May 2019].

Draghi, M. and Constâncio, V. (2012b) Introductory statement to the press conference (with Q\&A), Frankfurt am Main, 2 August, available at: http://www.ecb.europa.eu/press/pressconf/2012/html/is120802.en.html (accessed 23 July 2018).

De Grauwe, P. (2013) 'The European Central Bank as Lender of Last Resort in the Government Bond Markets,' CESifo Economic Studies 59(3): 520-535.

De Grauwe, P. and Ji, Y. (2013) 'From Panic-Driven Austerity to Symmetric Macroeconomic Policies in the Eurozone," Journal of Common Market Studies 51(S1): 31-41.

ECB (European Central Bank) (2002) 'The accountability of the ECB', ECB Monthly Bulletin November: 45-57.

ECB (2011) 'The European Stability Mechanism', ECB Monthly Bulletin July: 71-84.

ECB (2012a) 'Technical features of Outright Monetary Transactions', Press release, 6 September, available at: http://www.ecb.europa.eu/press/pr/date/2012/html/pr120906_1.en.html (accessed 23 July 2018).

ECB (2012b) ‘Editorial,' ECB Monthly Bulletin August: 5-7.

ECB (2015) 'Press Release: ECB Governing Council takes note of ruling on OMT,' 18 June, available at: https://www.ecb.europa.eu/press/pr/date/2015/html/pr150618.en.html [accessed 22 May 2019].

ECB (2017a) Opinion of the European Central Bank of 4 October 2017 on a proposal for a regulation of the European Parliament and of the Council amending Regulation (EU) No 1095/2010 and Regulation (EU) No 648/2012 with regard to the procedures and authorities involved for the authorisation of central counterparties and the recognition of third country central counterparties (CON/2017/39). 
ECB (2017b) 'Why is the ECB independent?', web page created 12 January, available at: https://www.ecb.europa.eu/explainers/tell-me-more/html/ecb_independent.en.html (accessed 28 June 2018).

ECJ (European Court of Justice) (2015) Judgment of the Court (Grand Chamber), 16 June 2015, Case C 62/14 (Gauweiler and others vs. Deutscher Bundestag).

Ferejohn, J. and Pasquino, P. (2004) 'The law of the exception: A typology of emergency powers', I.CON 2(2): 210-239.

Fraccaroli, N., Giovannini, A. and Jamet, J-F. (2018) 'The evolution of the ECB's accountability practices during the crisis', ECB Economic Bulletin, issue 5.

Friedman, M. (1960) A program for monetary stability, New York: Fordham University Press.

GFCC (German Federal Constitutional Court) (2014a) 'Principal Proceedings ESM/ECB: Pronouncement of the Judgment and Referral for a Preliminary Ruling to the Court of Justice of the European Union,' Press release No. 9/2014, 7 February.

GFCC (2014b) Order of the Second Senate of 14 January 2014 - 2 BvR 2728/13 [preliminary reference in the case known as Gauweiler and Others v Deutscher Bundestag].

GFCC (2016) Judgment of the Second Senate of 21 June 2016 - 2 BvR 2728/13 [judgement in Gauweiler and others v Deutscher Bundestag].

GFCC (2017) Proceedings on the European Central Bank's expanded asset purchase programme are stayed - Referral to the Court of Justice of the European Union, press release No. 70/2017, 15 August, available at: https://www.bundesverfassungsgericht.de/SharedDocs/Pressemitteilungen/EN/2017/bvg1 7-070.html (accessed 14 November 2018).

Giavazzi, F., Portes, R., Weder di Mauro, B., and Wyplosz, C. (2013) 'The wisdom of Karlsruhe: The OMT Court case should be dismissed,' voxeu.org, 12 June, available at: https://voxeu.org/article/wisdom-karlsruhe-omt-court-case-should-be-dismissed [accessed 22 May 2019].

Goldoni, M. (2017) 'The limits of legal accountability of the European Central Bank,' George Mason Law Review 24(2): 595-616. 
Goodhart, C.A.E. (1998) 'The two concepts of money: implications for the analysis of optimal currency areas', European Journal of Political Economy 14: 407-432.

Gren, J. (2018) 'The Eurosystem and the Single Supervisory Mechanism: institutional continuity under constitutional constraints.' ECB Legal Working Paper Series No. 17/July 2018.

Habermas, J. (2015) 'Habermas: Warum Merkels Griechenland-Politik ein Fehler ist' Süddeutsche Zeitung [online], 22 June, available at: http://www.sueddeutsche.de/wirtschaft/europa-sand-im-getriebe-1.2532119 [accessed 22 May 2019].

Habermas, J., Bofinger, P., and Nida-Rümelin, J. (2012) 'Kurswechsel für Europa: Einspruch gegen die Fassadendemokratie', Frankfurter Allgemeine Zeitung, 3 August.

Hinarejos, A. (2015) The Euro Area Crisis in a Constitutional Perspective, Oxford: OUP. Hobbes, T. (1998) On the Citizen, Cambridge: CUP.

Howarth, D. and Quaglia, L. (2013) ‘Banking union as holy grail,' Journal Common Market Studies, 51: 103-123, doi:10.1111/jcms.12054

Ioannidis, M. (2016) 'Europe’s New Transformations: How the EU Economic Constitution Changed during the Eurozone Crisis', Common Market Law Review 53: 1237-1282. Issing, O. (2002) Should We have Faith in Central Bankers, London: Institute of Economic Affairs.

Juncker, J-C. (2018) 'State of the Union 2018. The Hour of European Sovereignty,' speech at the European Parliament, Luxembourg, 12 September, available at: https://ec.europa.eu/commission/sites/beta-political/files/soteu2018-speech_en_0.pdf [accessed 22 May 2019].

Laclau, E. (2005) On Populist Reason, London and New York: Verso.

Lamandini, M., Ramos, D. and Solana, J. (2016) “The European Central Bank (ECB) as a Catalyst for Change in EU Law. Part 1: The ECB's Mandates," Columbia Journal of European Law 23(1): 1-54. 
Lautenschläger, S. (2017) 'The European banking sector - growing together and growing apart', speech at the LSE German Symposium, London, 2 March, available at: https://www.ecb.europa.eu/press/key/date/2017/html/sp170302.en.html (accessed 23 July 2018).

Levinson, S. and Balkin, J.M. (2010) ‘Constitutional Dictatorship: Its Dangers and Its Design', Minnesota Law Review 94: 1789-1866.

Locke, J. (1988) Two Treatises of Government, Cambridge: CUP.

Lohmann, S. (2003) 'Why do institutions matter? An audience-cost theory of institutional commitment,' Governance 16(1): 95-110.

Loughlin, M. (2003) The Idea of Public Law, Oxford: OUP.

Mersch, Y. (2016) Introductory statement of the ECB in the oral hearing of the German Federal Constitutional Court in the OMT proceedings, Karlsruhe, 16 February, available at: https://www.ecb.europa.eu/press/key/date/2016/html/sp160216.en.html [accessed 22 May 2019].

Mersch, Y. (2017) 'Aligning accountability with sovereignty in the European Union: the ECB's experience,' in ECB Legal Conference 2017: Shaping a new legal order for Europe: a tale of crises and opportunities, Frankfurt: ECB.

Mundell, R.A. (2002) 'Monetary Unions and the Problem of Sovereignty', The Annals of the American Academy of Political and Social Science 579 (Exchange rate Regimes and Capital Flows): 123-152.

Papasavvas, C. (2015) 'Responsibility of the ECB in managing the European Debt Crisis: Towards a European Banking Union?', Law, Social Justice \& Global Development Journal 1: 1-37.

Praet, P (2015) 'The APP impact on the economy and bond markets,' intervention at the annual dinner of the ECB's Bond Market Contact Group, Frankfurt am Main, 30 June, available at: https://www.ecb.europa.eu/press/key/date/2015/html/sp150630.en.html [accessed 22 May 2019]. 
Rossiter, C. (1948) Constitutional Dictatorship: Crisis Government in the Modern Democracies, Princeton: Princeton University Press.

Rousseau, J.J. (2012) Of the Social Contract and Other Political Writings, London: Penguin. Saka, O., Fuertes, A-M., and Kalotychou, E. (2015) 'ECB policy and Eurozone fragility: Was De Grauwe right?' Journal of International Money and Finance 54: 168-185.

Schmitt, C. (2005) Political Theology, Chicago, IL: University of Chicago Press.

Schmitt, C. (2014) Dictatorship, Cambridge: Polity.

Schulz, M. (2015) 'Award Speech,' in Award Ceremony for Prof Mark Blyth: Austerity - The History of a Dangerous Idea, Berlin: Friedrich Ebert Stiftung, p. 7-10.

Smits, R. (1997) The European Central Bank - Institutional Aspects, The Hague: Kluwer Law International.

Szczerbowicz, U. (2015) 'The ECB Unconventional Monetary Policies: Have They Lowered Market Borrowing Costs for Banks and Governments?' International Journal of Central Banking 11(4): 91-127.

Torres, F. (2013) 'The EMU's Legitimacy and the ECB as a Strategic Political Player in the Crisis Context,' Journal of European Integration, 35(3): 287-300, doi: 10.1080/07036337.2013.774784.

Tortola, P. D. and Pansardi, P. (2019) 'The charismatic leadership of the ECB presidency: A language-based analysis,' European Journal of Political Research 58: 96-116, doi:10.1111/1475-6765.12272.

Tuck, R. (2016) The Sleeping Sovereign: The Invention of Modern Democracy, Cambridge: CUP.

Tuori, K. (2012) 'The European Financial Crisis - Constitutional Aspects and Implications,' EUI Law Working Papers No. 28.

Tuori, Kaarlo and Tuori, Klaus (2014) The eurozone crisis: A constitutional analysis, Cambridge: CUP.

Verdun, A. (2017) 'Political leadership of the European Central Bank,' Journal of European Integration 39(2): 207-221, doi: 10.1080/07036337.2016.1277715 
White, J. (2015) 'Emergency Europe', Political Studies 63: 300-318.

Winkler, A. (2015) 'The ECB as Lender of Last Resort: Banks versus Governments,' Journal of Economics and Statistics (Jahrbücher für Nationalökonomie und Statistik) 235(3): 329341, doi: 10.1515/jbnst-2015-0307.

Zilioli, C. and Selmayr, M. (2001) The Law of the European Central Bank, Oxford: Hart Publishing. 